\title{
Uterine leiomyomatosis with intracardiac extension
}

\author{
Amari T Thompson, Anant Desai, Samuel J Ford, David Gourevitch
}

Queen Elizabeth Hospital Birmingham, Birmingham, UK

\section{Correspondence to} Dr Amari T Thompson, amari.thompson@doctors.org. uk

Accepted 3 December 2016

\section{DESCRIPTION}

A 40-year-old woman under investigation for a pelvic mass presented following a syncopal episode. A large fibroid-like pelvic mass and venous thrombus, extending from the left gonadal vein into the inferior vena cava and right atrium, were noted on CT scan (figures 1 and 2). She was referred to the nearest Sarcoma Unit; single-stage excision was planned.

At laparotomy, a 28-week uterus was found. Total abdominal hysterectomy with bilateral salpingo-oophrectomy was performed. The full length of the inferior vena cava and left renal vein were exposed while median sternotomy was undertaken. Following aorto-atrial cannulation, the patient was cooled to $18^{\circ} \mathrm{C}$ to induce cardioplegia. In the chest, cavotomy was performed inferior to the right atrium. Simultaneously, another cavotomy was performed at the level of the left renal vein. The tumour

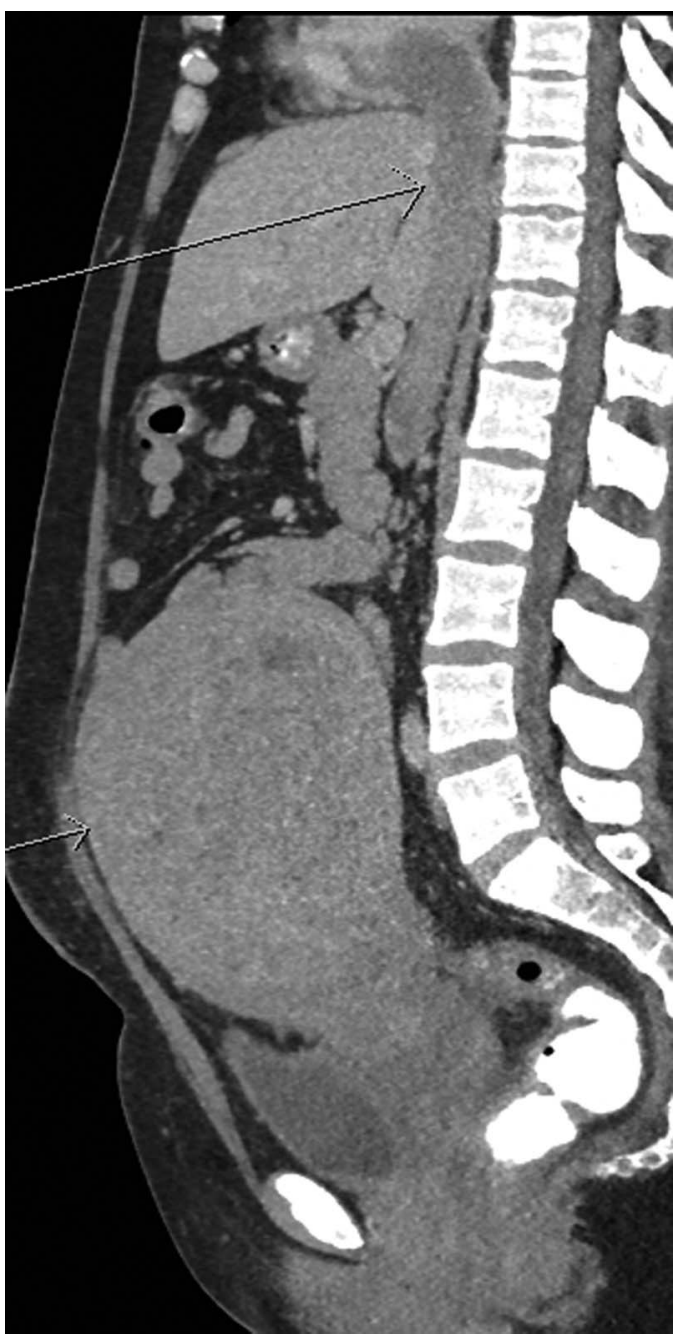

Desai A, Ford SJ, et al. BM Case Rep Published online: [please include Day Month Year] doi:10.1136/bcr-2016218234

CrossMark
Figure 1 Thrombus extending up inferior vena cava into the right atrium (superior arrow) with large uterine mass $(19.5 \times 16.7 \times 13.7 \mathrm{~cm})$ (inferior arrow).

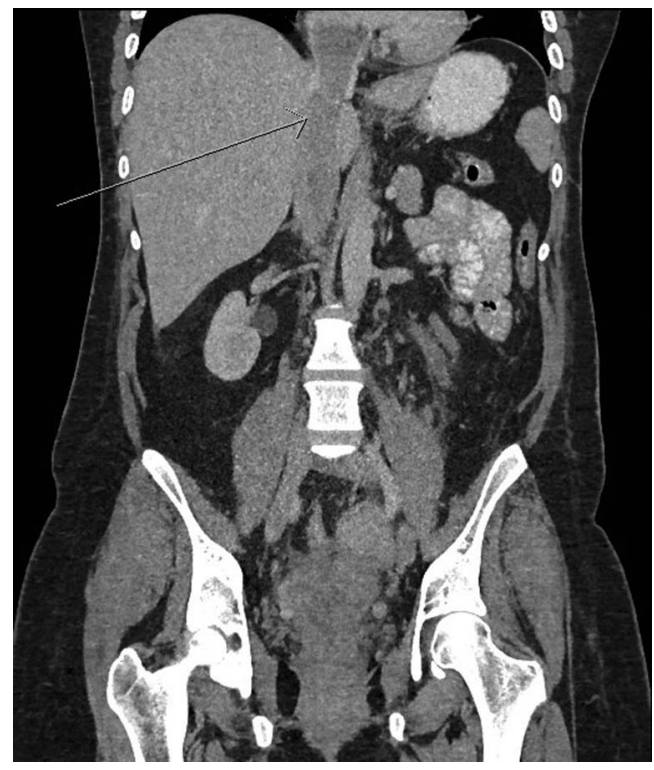

Figure 2 Thrombus extending up inferior vena cava into the right atrium.

was thus exposed, it was smooth and non-adherent, allowing it to be easily grasped and delivered through the lower cavotomy. Finally, more distal tumour thrombus, extending down the internal iliac vessel ramifications, was removed via the third, midcaval, incision. Histological analysis revealed uterine leiomyoma with intravenous leiomyomatosis.

Uterine leiomyomatosis is a common condition among women with $30 \%$ having extrauterine involvement and of these $10 \%$ are intracardiac ${ }^{1}$ It is benign and characterised histologically by the proliferation of smooth muscle cells arising from either the uterine myoma or the vessel wall. Patients commonly present with gynaecological symptoms such as abnormal uterine bleeding and pelvic pain. ${ }^{2}$ They may also complain of cardiac symptoms such as syncope, dysponea, chest pain and peripheral odema.

\section{Learning points}

- Uterine leiomyomatosis with cardiac extension can be suspected in patients presenting with abnormal uterine bleeding, palpable pelvic mass and cardiac symptoms.

- Extrauterine leiomyomatosis may be easily mistaken for a malignant condition due to the clinical findings and radiological appearances. It is, however, histologically benign, and radical surgery is therefore justified.

Contributors ATT drafted the article for submission and was involved in the patient's care. AD and DG were the lead surgeons 
in the case, the former being the admitting consultant. SJF, AD and DG reviewed the draft article and made amendments for submission.

Competing interests None declared.

Patient consent Obtained.

Provenance and peer review Not commissioned; externally peer reviewed.

\section{REFERENCES}

1 Li R, Shen Y, Sun Y, et al. Intravenous leiomyomatosis with intracardiac extension: echocardiographic study and literature review. Tex Heart Inst I 2014;41:502-6.

2 Zeng $H$, Xu Z, Zhang L, et al. Intravenous leiomyomatosis with intracardiac extension depicted on computed tomography and magnetic resonance imaging scans: a report of two cases and a review of the literature. Oncol Lett 2016;11:4255-63.

Copyright 2016 BMJ Publishing Group. All rights reserved. For permission to reuse any of this content visit

http://group.bmj.com/group/rights-licensing/permissions.

BMJ Case Report Fellows may re-use this article for personal use and teaching without any further permission.

Become a Fellow of BMJ Case Reports today and you can:

- Submit as many cases as you like

- Enjoy fast sympathetic peer review and rapid publication of accepted articles

- Access all the published articles

- Re-use any of the published material for personal use and teaching without further permission

For information on Institutional Fellowships contact consortiasales@bmjgroup.com

Visit casereports.bmj.com for more articles like this and to become a Fellow 